DOI:10.17951/h.2015.59.3.135

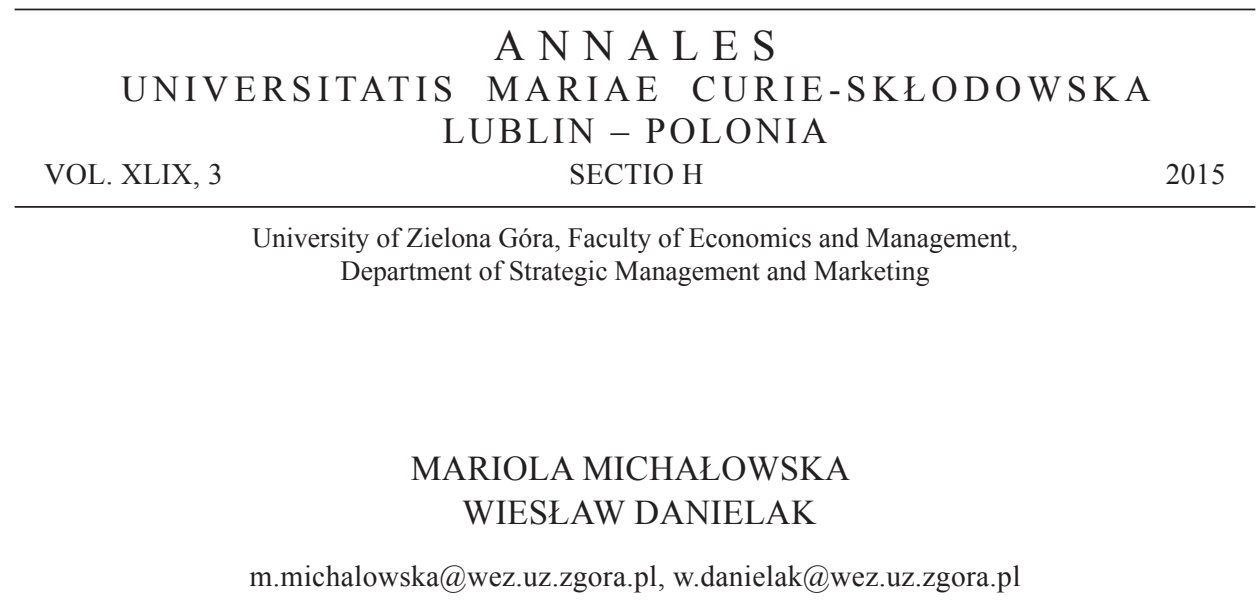

\title{
The Impact of Globalization on Consumer Behavior in Lubuskie Province in the Light of the Research
}

Wpływ globalizacji na zachowania konsumentów w województwie lubuskim w świetle badań

Keywords: globalization, consumer behavior, Lubuskie province.

Słowa kluczowe: globalizacja, zachowania konsumentów, województwo lubuskie.

JEL Code: D12

\section{Introduction}

Consumer behavior, cultural factors and conditions that determine them are the subject of much research and reflection. Changes associated with the perception of consumption have changed dramatically over the centuries. But what remains unchanged is the fact that consumption plays a special role in the society. Undoubtedly, the development of market economy, the continuing process of globalization, technological progress, and rising living standards have created a kind of consumer culture in which people strive to best meet their needs. Giddens noted that in the context of globalization, however, we have stood in the face of the return towards the new individualism, which is, actively forming our self-identities (Giddens, 2008, p. 84). The pursuit of individualism, creating our own separate identity, style of behavior, attitudes, tastes, or preferences are only some attempts to stand out, since, according to Bourdieu's thesis „taste classifies, by classifying the person who is 
classifying: social actors are different by distinctions (...), in which their position is noted or marked in the objective classifications" (2005, p. 15). The author in the following discussion points out that there are some differences that are reflected in the development of human society, because ,the ideology of natural taste derives its manifestations and its effectiveness from neutralizing real differences, transforming the natural differences - differences in the ways of acquiring culture" (Bourdieu, 2005, p. 15) and thus, the consumption of goods and services. According to Macdonald, mass culture ,is a dynamic, revolutionary force that eradicates class divisions, tradition, taste and blurs cultural distinctions" (Macdonald, 2002, p. 482). Mass culture influences the development of consumer behavior, their preferences, lifestyle. However, as it was noted by Mazurek-Łopacińska, consumer susceptibility to the adoption of global products depends on the strength of the association with the local culture. Unstable products have a stronger relationship with the culture and their purchase is an expression of shopping habits, customs, and traditions of individual nations (Mazurek-Łopacińska, 2003, p. 35). It is worth noting that there is no single common position on how purchasing decisions are determined by global trends, and to what extent are the result of cultural conditioning.

The literature points to a number of factors influencing the globalization of consumption and, on the other hand, inhibiting it. Among the factors contributing to the globalization of consumption Mazurek-Łopacińska distinguishes a desire for a modern, more attractive lifestyle, seeking convenience products, quality, and purchasing as a way to enhance the status of global consumers to underdeveloped countries. In contrast, agents that block the globalization of consumption are, for example, national attitudes that cause people to favor domestic production, consumer ethnocentrism, unemployment (Mazurek-Łopacińska, 2003, p. 34). In addition, the analysis of buyers' behavior in the research on the effect of country of origin shows that there are significant differences between the behavior of consumers in developed countries compared to consumers in underdeveloped countries, or depending on the country, the target group, or the type of goods. Among consumers in developed countries, there is a tendency to prefer products from their own country, while buyers in underdeveloped countries often choose foreign products (Sikora, 2008, pp. 173-184). This is particularly true of high-tech products. In addition, manufacturers with national roots are often more favored by older people and people with lower education, while this factor is the least important for people with higher education (Sikora, 2008, p. 176).

\section{The level and structure of household expenditure in the region of Lubuskie province}

The level of the average monthly income per household and the share of expenditure in disposable income in 2013 amounted to PLN 1238.06, while spending stood at PLN 1005.29. (Figure 1). 


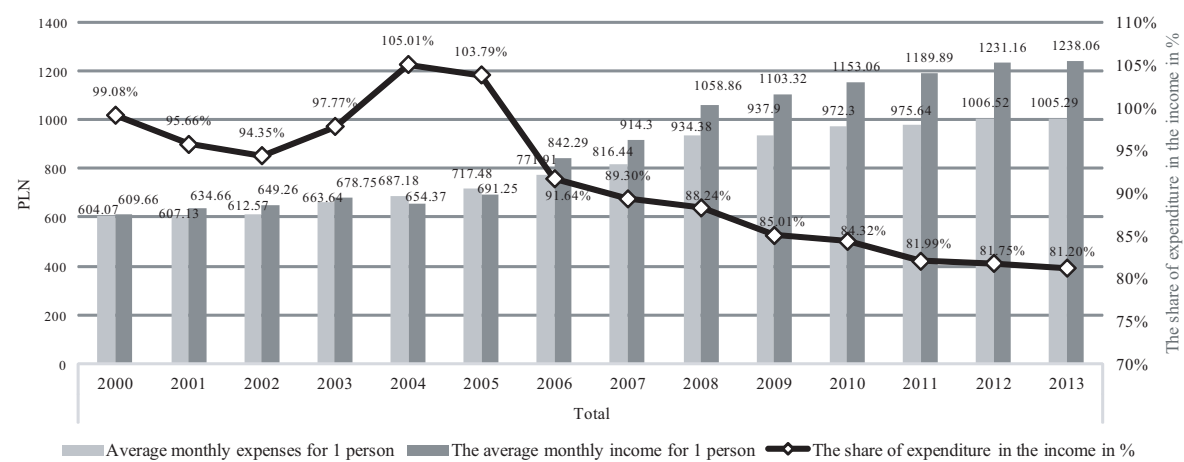

Figure 1. Level of average monthly income and expenditure per person in the household and the share of expenditure in disposable income in the years 2000-2013

Source: Bank Danych Lokalnych, Warszawa 2014

According to CSO, participation in disposable income in 2013 amounted to $81.20 \%$ and was lower by $0.55 \%$ than in 2012 (Figure 1 ). It is worth mentioning that in the years 2000-2013, with the exception of 2004 and 2005, the level of average monthly income per household increased steadily. It is worth noting that in the mentioned period 2004-2005, the level of average spending per household exceeded the level of average monthly income. Figure 2 shows the average monthly expenditure per person in the household of Lubuskie province in 2011.
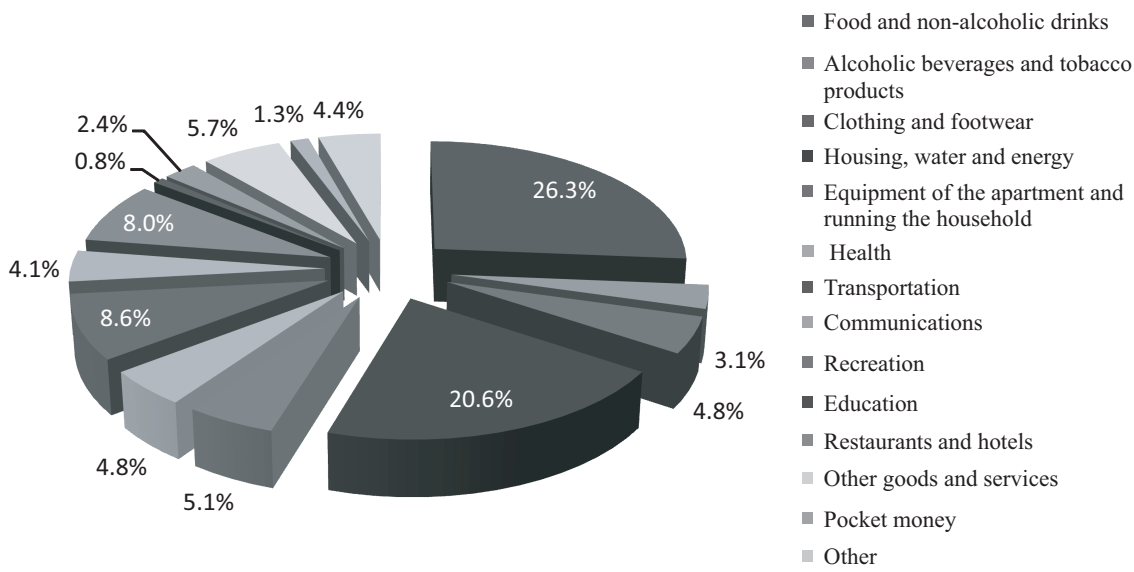

Figure 2. Average monthly expenditures per capita in households of Lubuskie province in 2011

Source: Diagnoza społeczna województwa lubuskiego..., p. 11 [Date of access: 15.10.2014]

According to the results of the study presented in the report entitled Social Diagnosis of Lubuskie Province (Figure 2), the inhabitants spend the greatest part of their average expenditure on food and soft drinks $(26.3 \%)$. In the next place were 
expenses related to the use of housing and energy carriers (20.6\%). It is worth noting that a large part of the average monthly expenditure per person in the household is spent on transport $(8.6 \%)$. And the smallest proportion of their average spending goes to education (about $1 \%$ ).

\section{New developments and trends in the sphere of consumption as determinants of consumer behavior}

Human life, like any living organism, is associated with the consumption and assimilation of food and, therefore, the development of human civilization is closely connected with satisfying the basic physiological needs (Gawęcki, 2000, p. 11). Human nutrition is one of the basic conditions of one's life, development, health and fitness, as well as a source of satisfaction to meet the social and hedonistic needs (Berger, 2000, p. 18). At the same time, changes associated with the perception of consumption have dramatically changed over the centuries. Nutrition serves not only as a means to satisfy hunger, but is also a source of pleasure and a common way of spending time with family/friends. The higher the rank of family/social life, the more the perception of the treatment of consumption is changing, becoming not only a way of satisfying hunger.

The development of the food market in Poland is determined not only by economic, demographic, social, and technological mega- and micro-trends, but also depends on the specifics of both regional and local production and consumption of food, as well as general trends of adaptation that generate the occurrence of new phenomena and consumption trends (Sojkin, Małecka, Olejniczak, Bakalarska, 2009, p. 11). Today, one may notice new phenomena and trends in the sphere of consumption, which include:

- Deconsumption and proconsumption - conscious reduction of the size of rational consumption;

- Increasing the importance of values such as health, good looks and physical state to improve the quality of life;

- Different attitudes of consumers towards foreign products (ethnocentrism, cosmopolitanism, internationalism) (Sojkin, Małecka, Olejniczak, Bakalarska, 2009, p. 11);

- Consumers becoming „multicultural” as a result of living in a multicultural world;

- Appreciation of the importance of following the relationship between man and nature, manifested in supporting efforts to protect the environment and in the pursuit of acquisition and consumption of organic products (Mazurek-Łopacińska, 2003, p. 29).

Consumers' decisions to purchase a product are affected by their daily life situation and the influence to which they are subjected at the point of purchase (Plichta, 2004, p. 93). Among the factors that determine the purchase we can distinguish, for instance, 
economic, psychological, or socio-cultural. The image of the country of origin is essential for the formation of consumers' attitudes to foreign products. It is referred to as the impact that the image of the country has on consumers that evaluate products coming from this country. A specific type of country of origin effect is consumer ethnocentrism (Figiel, 2004, p. 32). The concept of ethnocentrism was first formulated by Sumner in 1906 as a ,way of looking at the world in which the own group is seen as the center of the world and everything around is evaluated and classified in relation to him/her" (Khan, Rizvi 2008). According to Sharma, Shimp and Shin consumer ethnocentrism is ,a belief shared by consumers on the renunciation to purchase products of foreign origin in the context of the duty and morality" (2004, p. 32). The consumer can identify the country of origin of the product based on the following factors: the sign ,made in”, the name of the product and its contact details, brand, product description language, national quality symbols, barcode (Figiel, 2004, p. 32).

The main objective of the study was to identify and evaluate the effects of consumption on global trends in consumer behavior and an indication of the factors that are crucial in consumers' purchasing decisions in Lubuskie province.

\section{Organization of research, sample size and selection}

The survey involved a group of 285 respondents of different age groups in Lubuskie province. The study was conducted from May to November 2014. The subjects were divided into age groups: under $19,19-34,35-44,45-55$, over 55 years of age. Test sample was selected randomly. The structure of the respondents in terms of gender and age is shown in Table 1.

Table 1. Structure of respondents by gender and age

\begin{tabular}{|c|c|c|c|c|c|c|c|}
\hline \multirow{2}{*}{ Specification } & \multirow{2}{*}{$\begin{array}{c}\text { Total } \\
\text { number }\end{array}$} & \multirow{2}{*}{$\begin{array}{c}\text { Share } \\
{[\%]}\end{array}$} & \multicolumn{6}{|c|}{ Age [years] [\%] } \\
\cline { 4 - 8 } & & & under 19 & $19-34$ & $35-44$ & $45-55$ & over 55 \\
\hline Women & 184 & 64.6 & - & 16.5 & 22.5 & 11.6 & 14.0 \\
\hline Men & 101 & 35.4 & 0.3 & 7.4 & 6.7 & 16.1 & 4.9 \\
\hline Total & 285 & 100.0 & 0.3 & 23.9 & 29.2 & 27.7 & 18.9 \\
\hline
\end{tabular}

Source: own study based on conducted research

The study included 285 respondents, of which approximately $65 \%$ were female and over $35 \%$ were male. The largest percentage of people were in the age range of 35-44 years. And the smallest in the range below 19 years.

\section{Conclusions of test results}

Table 2 shows respondents' opinions on the importance of Polish origin when buying food products. Respondents assessed each product on a six-grade scale. 
Pobrane z czasopisma Annales H - Oeconomia http://oeconomia.annales.umcs.pl

Data: 26/04/2023 15:31:33

MARIOLA MICHAŁOWSKA, WIESŁAW DANIELAK

Table 2. Opinions of respondents on the importance of Polish origin when buying food products

\begin{tabular}{|l|c|c|c|c|c|c|c|}
\hline \multirow{2}{*}{ Specification } & \multicolumn{3}{|c|}{ The importance of Polish origin on the six-grade scale [\%] } & Teither \\
\cline { 2 - 7 } & $\begin{array}{c}\text { Very } \\
\text { important }\end{array}$ & Important & $\begin{array}{c}\text { Norge nor } \\
\text { small }\end{array}$ & Small & $\begin{array}{c}\text { Very } \\
\text { small }\end{array}$ & $\begin{array}{c}\text { It does } \\
\text { not } \\
\text { matter }\end{array}$ & $\begin{array}{c}\text { Total } \\
{[\%]}\end{array}$ \\
\hline Vegetables & 76.8 & 23.2 & - & - & - & - & 100.0 \\
\hline Fruit & 22.8 & 38.9 & 30.9 & 7.4 & - & - & 100.0 \\
\hline $\begin{array}{l}\text { Bakery and confectionery } \\
\text { products (bread, rolls, cakes) }\end{array}$ & 27.7 & 72.3 & - & - & - & - & 100.0 \\
\hline $\begin{array}{l}\text { Milk and milk products (dairy } \\
\text { products) }\end{array}$ & 89.8 & 10.2 & - & - & - & - & 100.0 \\
\hline Meat and meat products & 68.8 & 31.2 & - & - & - & - & 100.0 \\
\hline Fish and fish products & 6.7 & 41.1 & 35.4 & - & - & 16.8 & 100.0 \\
\hline $\begin{array}{l}\text { Sweets and sweet snacks } \\
\text { (chocolate, waffles, etc.) }\end{array}$ & - & 11.9 & 29.8 & 33.7 & 2.5 & 22.1 & 100.0 \\
\hline $\begin{array}{l}\text { Salty snacks (salty sticks, chips, } \\
\text { etc.) }\end{array}$ & - & 8.1 & 19.6 & 4.6 & 27.4 & 40.3 & 100.0 \\
\hline Alcohol & - & - & - & - & 16.1 & 83.9 & 100.0 \\
\hline Beverages & 46.3 & 19.6 & 4.6 & - & 8.4 & 21.1 & 100.0 \\
\hline
\end{tabular}

Source: own study based on conducted research

Considering the data presented in Table 2, it should be stressed that the Polish origin of the products is important for respondents when purchasing vegetables, bakery and confectionery products, dairy products, as well as meat and sausages. In the case of fruit, Polish origin is essential for approx. $62 \%$ respondents; $31 \%$ respondents have indicated a neutral response, while over $7 \%$ respondents said this factor has little meaning. Fish - approx. 48\% people declared that their Polish origin matters to them, over $35 \%$ respondents remained neutral while for about $17 \%$ subjects it is not at all important. It is worth noting that for every second respondent, beverages of Polish origin are important, and for every twelfth, it is not critical, while for every fifth it did not matter. In contrast, every twenty-second respondent did not opt for any option, selecting a neutral response. It is clear from the research that Polish sweets and sugary snacks are important only for approx. $12 \%$ people. Thirty percent declared that they have no preference, approx. $34 \%$ it does not matter much, and over $2 \%$ respondents said it has very little meaning. Twenty two percent of people have stated that for them there is no significance whether products are of Polish origin or not. In the case of salty snacks it is relevant for $8 \%$ people, $20 \%$ are not in favor of any option and chose a neutral response. The least important is the origin of salty snacks. Approximately $32 \%$ people stated it was not of high significance and for over $40 \%$ respondents it did not matter. It should be noted that for the respondents, Polish origin is the least important when it comes to alcohols since for only $16 \%$ it is of little importance, and for approx. $84 \%$ it is irrelevant.

Increasing consumer nutrition awareness contributes to the growth of interest in food which is conducive to maintaining health, well-being and maintaining physical and mental fitness. Food is designed not only to satisfy hunger, but also to improve 
its functioning and prevent a variety of diseases (Woś, Rochacka, Kasperek-Hoppe, 2004, p. 119). Popularity of organic foods is also accompanied by other changes in food preferences of consumers because the consumption of popular products with a low calorific value is replaced by the so-called fashion for consuming balanced products, which contain appropriate vitamins and nutrients (Woś, Rochacka, Kasperek-Hoppe, 2004, p. 119). It is worth noting that today's buyers are becoming more demanding and expect individual treatment, a wide range of commercial products tailored to their needs and expectations. It should also be noted that the implementation of environmental needs as the main reason for the purchase is relatively rare in relation to products of daily use and is strongly dependent on the level of consumer awareness (Adamczyk, 2004, p. 26). Respondents were also asked to identify factors influencing the purchase of food products (Table 3).

Table 3. Factors influencing the purchase of food products

\begin{tabular}{|l|c|c|c|}
\hline \multicolumn{1}{|c|}{ Specification } & $\begin{array}{c}\text { Number of } \\
\text { indications }\end{array}$ & $\begin{array}{c}\text { Percentage of } \\
\text { indications }\end{array}$ & $\begin{array}{c}\text { Percentage of } \\
\text { respondents }(\mathrm{n}=285)^{*}\end{array}$ \\
\hline Good price & $\mathbf{1 6 8}$ & $\mathbf{1 2 . 5}$ & $\mathbf{5 8 . 9}$ \\
\hline Freshness of the products & 154 & 11.4 & $\mathbf{5 4 . 0}$ \\
\hline Taste & 117 & 8.7 & $\mathbf{3 8 . 9}$ \\
\hline Brand & 111 & 8.2 & $\mathbf{3 7 . 9}$ \\
\hline Quality & 108 & 8.0 & 35.4 \\
\hline Health benefits & $\mathbf{1 0 1}$ & $\mathbf{7 . 5}$ & 34.7 \\
\hline Nutritional value & $\mathbf{9 9}$ & $\mathbf{7 . 3}$ & 34.0 \\
\hline The composition of the product & $\mathbf{9 7}$ & $\mathbf{7 . 2}$ & 32.3 \\
\hline Polish origin of the product & $\mathbf{9 2}$ & $\mathbf{6 . 8}$ & 30.2 \\
\hline Trade promotions & $\mathbf{8 6}$ & $\mathbf{6 . 4}$ & 20.7 \\
\hline Advertising & $\mathbf{5 9}$ & $\mathbf{4 . 5}$ & 16.1 \\
\hline Date of manufacturing & $\mathbf{4 6}$ & $\mathbf{3 . 4}$ & 7.4 \\
\hline The size of the package & $\mathbf{2 1}$ & $\mathbf{1 . 6}$ & 6.7 \\
\hline No preservatives/Ecology & $\mathbf{1 9}$ & $\mathbf{1 . 4}$ & 6.3 \\
\hline Tradition & $\mathbf{1 8}$ & $\mathbf{1 . 3}$ & 5.6 \\
\hline Opinions of the family/ friends/online forums & $\mathbf{1 6}$ & $\mathbf{1 . 2}$ & 4.6 \\
\hline Foreign origin of the product & $\mathbf{1 3}$ & $\mathbf{1 . 0}$ & 3.9 \\
\hline Reputation of the manufacturer & $\mathbf{1 1}$ & $\mathbf{0 . 8}$ & 2.5 \\
\hline Loyalty to the manufacturer & $\mathbf{7}$ & $\mathbf{0 . 5}$ & 0.7 \\
\hline Attractive packaging & $\mathbf{3}$ & $\mathbf{0 . 2}$ & - \\
\hline Habit & $\mathbf{0 . 1}$ & $\mathbf{1 0 0 . 0}$ & \\
\hline Total & & & \\
\hline
\end{tabular}

* Percentage of respondents does not add up, the respondent could provide up to $100 \%$ more than one answer.

Source: own study based on conducted research

On the basis of the data contained in the Table, it can be seen that for approx. $59 \%$ of respondents the most important factor is the price of the products they purchase. Freshness, taste, brand and quality, as well as health benefits also have a strong influence on purchasing decisions. An important factor for respondents 
(over 33\%) is also the nutritional value of products. For $32 \%$ the composition of the product was relevant and for over $34 \%$ it was the Polish product origin. According to the study, out of 285 respondents, every third decided to purchase trade promotions, while every fifth is influenced by advertising and every sixth by the date of manufacturing. In contrast, the size of the package was relevant to every fourteenth respondent, no preservatives / ecology to every fifteenth respondent, tradition to every sixteenth, and the opinions of family / friends / online forums to every eighteenth. It is worth noting that foreign origin of the product was relevant to every twenty-second respondent. Reputation of the manufacturer, loyalty to the manufacturer, attractive packaging, as well as purchasing habits were considered the least important factors.

Along with changes in the food trade, changes in consumer behavior in Lubuskie province are reflected. Development of new forms of trade meant that the customer has a wide range of space and time to make purchases in order to meet one of the basic human needs that is the need to satisfy hunger (Table 4).

Table 4. The most frequently chosen store for everyday purchases

\begin{tabular}{|l|c|c|}
\hline Specification & $\begin{array}{c}\text { Number of } \\
\text { answers }\end{array}$ & $\begin{array}{c}\text { The percentage } \\
\text { of answers [\%] }\end{array}$ \\
\hline Hypermarket & 99 & 34.7 \\
\hline Discount store & 69 & 24.2 \\
\hline Supermarket & 42 & 14.7 \\
\hline Traditional Shop & 29 & 10.2 \\
\hline Marketplaces & 24 & 8.4 \\
\hline Convenient store & 21 & 7.4 \\
\hline Healthy food store & 1 & 0.4 \\
\hline Total & 285 & 100.0 \\
\hline
\end{tabular}

Source: own study based on conducted research

The dynamic development of retail has an impact on consumer behavior in the selection of the store as a place for shopping. Research indicates the importance of large retail chains, i.e. hyper- and supermarkets, discount stores in the life of the inhabitants of the Lubuskie province. Based on these results, it was observed that the abovementioned stores sell to about $74 \%$ of the respondents. About $35 \%$ of respondents chose the hypermarket, more than $14 \%$ the supermarket, and more than $24 \%$ chose the discount store. It is also worth noting that every 10 th respondent goes to a traditional shop, and every 14th respondent to the convenient store, and every 12th person tends to choose the marketplace in order to make everyday purchases. The smallest number of indications was received by the healthy food store, since only one person has declared to make purchases in it. Figure 3 shows the reasons for buying Polish products. 


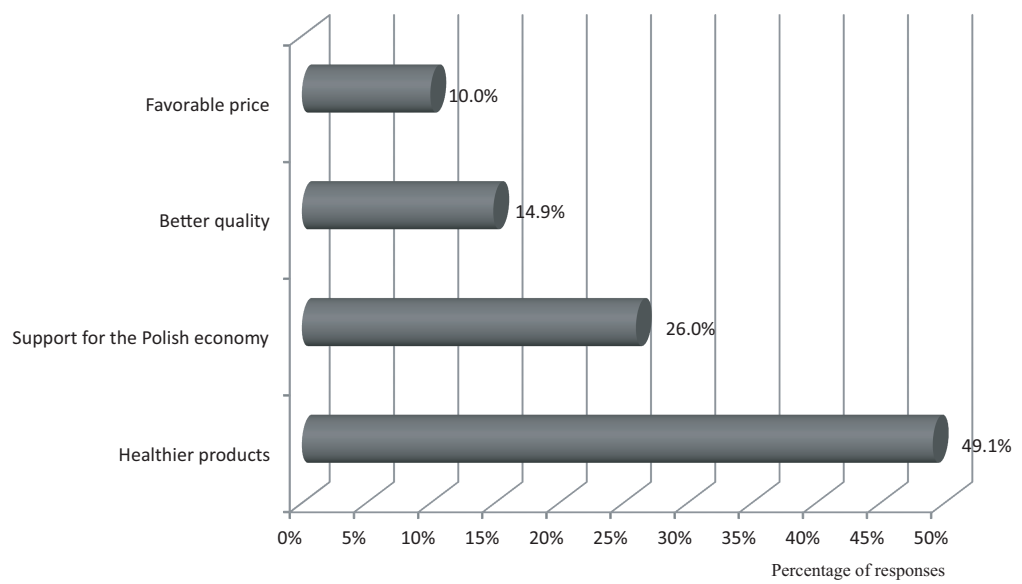

Figure 3. The reasons for buying Polish products (percentage of indications)

Source: own study based on conducted research

Shown results indicate that the main reasons for buying Polish products are, in the opinion of respondents, healthier products compared with products from other countries (percentage of indications over 49\%). In the second place there is the support for the Polish economy (percentage of indications 26\%), followed by better quality (percentage of indications approx. 15\%). It should also be noted that every seventh respondent selects Polish products due to favorable price.

Respondents were also asked about preferences for food consumption (Figure 4 ) and the degree of acceptance of new products on the market (Figure 5).

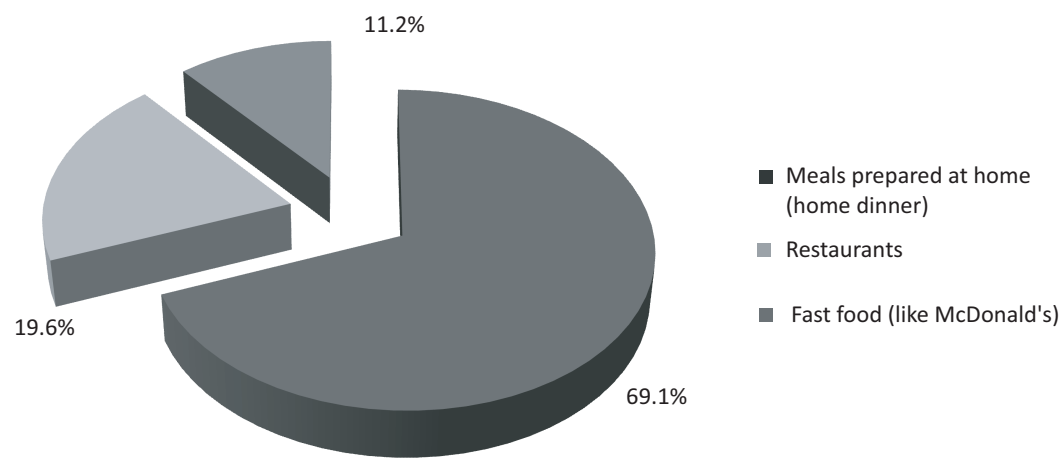

Figure 4. Preferences for food consumption

Source: own study based on conducted research

On the basis of the data included in the Figure it can be stated that over $69 \%$ of respondents prefer meals prepared at home, every 5 th consumer goes to a restaurant, and every 9 th to fast food restaurants. 

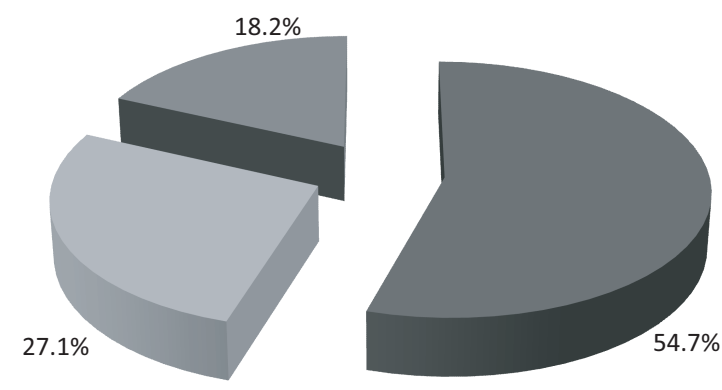

- I buy new products when they appear on the market

I buy the product when others have already bought it and expressed positive opinions about it

- I do not buy new products on market

Figure 5. The degree of acceptance of new products on the market

Source: own study based on conducted research

In the context of the responses regarding the acceptance of new products on the market, more than half of the respondents i.e. approx. 55\% buy new products as soon as they appear on the market, over $27 \%$ buy products which others have already bought and have expressed positive opinions about. However, over $18 \%$ are not purchasing new products on the market.

\section{Summary}

Along with the changes in the food trade, changes in consumer behavior in Lubuskie province are reflected. The globalization of the food market substantially influenced the behavior of consumers by creating the possibility of using newly developed products and any developments while respecting the products and traditional Polish meals prepared at home. Development of new forms of trade meant that the customer has not only a wide range of space but also time to make purchases in order to meet one of the basic human needs, that is the need to satisfy hunger. In the light of the conducted research it is showed that large-trading networks play an important role in consumers' everyday lives, becoming the most frequently chosen place for making everyday purchases for the majority of respondents. Given consumer behavior is related to the average monthly per capita expenditure of households in Lubuskie province. The largest part of their average expenditure is spent on food and soft drinks. The research found that depending on the type of the product, Polish origin of the product becomes of more or less importance to the respondents. For respondents Polish origin is most important when it comes to purchasing vegetables, bakery and confectionery products, dairy products, as well as meat and sausages, and the main reason for the purchase is the belief that Polish products are healthier than the products of foreign origin. The least important in terms of Polish origin is alcohol. It should also be noted that the globalization of consumption means that 
more and more consumers are choosing food products with novelty features as soon as they appear on the market.

In the opinion of the authors, it becomes necessary in the future to carry out research in the context of identifying factors influencing the globalization of consumption, and on the other hand, factors inhibiting it, indicating the main drivers of consumer choice and direction of anticipated changes in relation to both food and non-food products.

\section{References}

1. Adamczyk W., Ekologia wyrobów. Jakość. Cykl życia. Projektowanie, Polskie Wydawnictwo Ekonomiczne, Warszawa, 2004.

2. Bank Danych Lokalnych, Warszawa, 2014.

3. Berger S., Historia nauki o żywieniu, [in:] J. Gawęcki, L. Hryniewiecki, Żywienie człowieka. Podstawy nauki o żywieniu, Wydawnictwo Naukowe PWN, Warszawa, 2000.

4. Bourdieu P., Dystynkcja. Społeczna krytyka władzy sadzenia, Wydawnictwo Naukowe SCHOLAR, Warszawa, 2005.

5. Diagnoza społeczna województwa lubuskiego, Załącznik do strategii polityki społecznej województwa lubuskiego na lata 2014-2020, http://lubuskie.pl/uploads/Zalacznik\%20do\%20projektu\%20Strategii. pdf [Date of access: 15.10.2014].

6. Figiel A., Etnocentryzm konsumencki. Produkty krajowe czy zagraniczne, PWE, Warszawa, 2004.

7. Gawęcki J., Człowiek i jego pokarm, [in:] J. Gawęcki, L. Hryniewiecki, Żywienie człowieka. Podstawy nauki o żywieniu, Wydawnictwo Naukowe PWN, Warszawa, 2000.

8. Giddens A., Socjologia, Wydawnictwo Naukowe PWN, Warszawa, 2008.

9. Khan M.N., Rizvi S.R., Consumer Ethnocentrism: Relevance and Implications for Marketers, The Icfai Journal of Consumer Behaviour 2008, Vol. III, No. 1.

10. Macdonald D., Teoria kultury masowej, [in:] Cz. Milosz (ed.), Kultura masowa, Wydawnictwo Literackie, Kraków, 2002.

11. Mazurek-Łopacińska K., Zachowania nabywców i ich konsekwencje marketingowe, PWE, Warszawa, 2003.

12. Plichta J., Merchandising, [in:] J. Szumilak (ed.), Handel detaliczny, funkcjonowanie i kierunki rozwoju, Oficyna Ekonomiczna, Kraków, 2004.

13. Sharma S., Shimp T., Shin J., Consumer Ethnocentrism. Construction and Validation of the Scale, Journal of Marketing Research, 1987, [in:] A. Figiel, Etnocentryzm konsumencki. Produkty krajowe czy zagraniczne, PWE, Warszawa, 2004.

14. Sikora T., Znaczenie efektu kraju pochodzenia dla komunikacji w biznesie międzynarodowym, Zeszyty Naukowe KGŚ SGH, 2008, No. 23.

15. Sojkin B., Małecka M., Olejniczak T., Bakalarska M., Konsument wobec innowacji produktowych na rynku żywności, Wydawnictwo Uniwersytetu Ekonomicznego w Poznaniu, Poznań, 2009.

16. Woś J., Rochacka J., Kasperek-Hoppe M., Zachowania konsumentów-teoria i praktyka, Wydawnictwo Akademii Ekonomicznej w Poznaniu, Poznań, 2004. 


\section{The Impact of Globalization on Consumer Behavior in Lubuskie Province in the Light of the Research}

Abstract. The development of market economy, the continuing process of globalization, technological progress, and rising living standards have created a kind of consumer culture in which people strive to best meet their needs. Undoubtedly, mass culture influences the development of consumer behavior, their preferences, lifestyle. Currently, there is no single common position on how purchasing decisions are determined by global trends, and to what extent they are the result of cultural conditioning. The main objective of the study was to identify and evaluate the effects of consumption on global trends in consumer behavior and an indication of the factors that are crucial in consumers' purchasing decisions in Lubuskie province. In this study we have used an analysis of the literature and the results of a survey conducted among respondents in Lubuskie province.

\section{Wpływ globalizacji na zachowania konsumentów w województwie lubuskim w świetle badań}

Abstrakt. Rozwój gospodarki wolnorynkowej, postępujący proces globalizacji, postęp techniczny i technologiczny, wzrost poziomu życia doprowadziły do wytworzenia pewnego rodzaju kultury konsumpcyjnej, w której człowiek dąży do jak najlepszego zaspokojenia swoich potrzeb. Niewątpliwie kultura masowa wpływa na kształtowanie zachowań konsumentów, na ich preferencje, styl życia. Aktualnie nie ma jednego wspólnego stanowiska dotyczącego na ile decyzje zakupowe determinowane są trendami globalnymi, a na ile wynikają z uwarunkowań kulturowych. Głównym celem opracowania było określenie i ocena skutków oddziaływania globalnych trendów konsumpcji na zachowania konsumentów, a także wskazanie czynników, które mają kluczowe znaczenie w decyzjach zakupowych konsumentów województwa lubuskiego. W opracowaniu wykorzystano analizę literatury oraz wyniki z przeprowadzonego badania ankietowego wśród respondentów w województwie lubuskim. 